\title{
\begin{tabular}{ll}
$\begin{array}{l}\text { Journal of Educational } \\
\text { Chemistry }\end{array}$ & $\begin{array}{l}\text { Journal of Educational Chemistry (2 (2), 2020, 49-56) } \\
\text { Website: https://www.journal.walisongo.ac.id/index.php/jec } \\
\text { ISSN 2715-3029 (p) 2685-4880 (e) } \\
\text { DOI: } 10.21580 / \text { jec.2020.2.2.6076 }\end{array}$ \\
\hline
\end{tabular}
}

\section{Pemanfaatan Jurnal Refleksi sebagai Penuntun Siswa dalam Menemukan Makna pada Mata Pelajaran Kimia}

\author{
Elisabeth Wulan Kainde1, Candra Yulius Tahya ${ }^{2}$ \\ 1,2Pendidikan Kimia, Universitas Pelita Harapan \\ E-mail: ${ }^{1}$ kaindeelisabeth@gmail.com, ${ }^{2}$ candratahya@uph.edu
}

\begin{abstract}
The process of finding meaning occurs when students are able to construct a complete concept so that it can give birth to action and responsibility. The Field Experience Program (PPL) which was implemented at a school in Jakarta focused on completing the material, showing different responses such as enthusiasm and unenthusiasm. This study will discuss questions about why and how a reflection journal can be a guide for students in finding meaning in Chemistry subjects. This research was conducted using the literature study method. The main data sources in this study used various journals and books, while additional data sources were the results of teacher reflections while teaching and the results of students' reflections while learning. Based on the discussion, it was found that the reflective journal can be used as a tool to link initial knowledge and new knowledge into a significant concept that generates responsible responses. This reflection journal is important to apply because it can be a means for teachers to create a thinking space that goes beyond learning material with correct understanding and response.
\end{abstract}

Keywords: chemistry; meaningful learning; reflection 


\begin{abstract}
Abstrak
Proses penemuan makna terjadi ketika siswa mampu mengkonstruk suatu konsep utuh sehingga dapat melahirkan tindakan dan tanggung jawab. Program Pengenalan Lapangan (PPL) yang dilaksanakan di salah satu sekolah di Jakarta terfokus pada penyelesaian materi menunjukkkan respon berbeda-beda seperti sikap antusias dan tidak antusias. Kajian ini akan membahas pertanyaan tentang mengapa dan bagaimana jurnal refleksi dapat menjadi penuntun siswa dalam menemukan makna pada mata pelajaran Kimia. Penelitian ini dilakukan dengan menggunakan metode studi literatur. Sumber data utama pada penelitian ini digunakan berbagai jurnal dan buku sedangkan sumber data tambahan berupa hasil refleksi guru saat mengajar serta hasil refleksi siswa saat belajar. Berdasarkan pembahasan, diperoleh bahwa jurnal refleksi dapat digunakan sebagai alat untuk mengaitkan pengetahuan awal dan pengetahuan baru menjadi satu konsep signifikan yang melahirkan respon bertanggung jawab. Jurnal refleksi ini penting untuk diterapkan karena dapat menjadi sarana bagi guru untuk menciptakan ruang berpikir yang melampaui materi pembelajaran dengan pemahaman dan respon yang benar.
\end{abstract}

Kata Kunci: kimia; pembelajaran bermakna; refleksi

\section{Pendahuluan}

Bagian Pembelajaran bermakna menurut teori Ausubel adalah keadaan ketika siswa mampu mengaitkan pengetahuan awal dan pengetahuan baru (West \& Fensham, 2014). Sejatinya, pengetahuan bermakna tidak hanya berhenti pada level kognitif, tetapi pembelajaran bermakna seharusnya menghasilkan respon yang bertanggung jawab (Van Brummelen, 2009). Berdasarkan pengertian ini, pembelajaran bermakna merupakan keadaan ketika siswa menemukan suatu konsep baru yang menghasilkan respon bertanggung jawab melalui proses mengaitkan pengetahuan awal dan pengetahuan baru.

Pembelajaran bermakna diharapkan dapat diterapkan dalam pembelajaran kimia agar siswa tidak hanya mempelajari materi tetapi dapat menemukan konsep signifikan yang dibangun dari konsep-konsep yang dipelajari di dalam kimia sehingga dapat menghasilkan respon bertanggung-jawab. Pembelajaran

50

Copyright (C) 2020 JEC | ISSN 2715-3029 (p) 2685-4880 (e)

Volume 2, Nomor 2, 2020 bermakna dibutuhkan karena karakteristik pembelajaran kimia ini sering dianggap sulit dan membosankan (Indira, 2014). Kimia merupakan bagian dari Ilmu Pengetahuan Alam yang mempelajari gejala alam namun secara khusus mempelajari struktur, susunan, sifat, perubahan, dan energi yang menyertainya (Argandi \& Martini, 2013). Penting bagi guru untuk menuntun siswa melihat Kimia tidak hanya sebatas teori yang tertulis di buku tetapi sebagai wujud eksplorasi dunia yang mengarah kepada Pencipta.

Kenyataan yang terjadi di dalam kelas saat Program Pengalaman Lapangan 2 di kelas X dengan jumlah siswa 23 di salah satu sekolah di Jakarta selama satu bulan, menunjukkan bahwa pembelajaran Kimia yang dilakukan guru masih terfokus pada materi tanpa memberikan ruang bagi siswa untuk memproses pembelajaran. Respon siswa yang ditunjukkan juga berbedabeda di setiap pembelajaran. Di tengah-tengah perbedaan metode mengajar guru, terkadang siswa kurang antusias dan bosan namun terkadang siswa bersemangat dan tertarik utuk 
belajar. Respon siswa yang berbeda-beda tersebut hanya merupakan hal-hal yang terlihat di permukaan. Jika guru hanya berfokus pada hal-hal yang hanya terlihat di permukaan ini dapat membuat guru sulit melihat proses yang sesungguhnya dialami siswa.

Berdasarkan permasalahan di atas, kajian ini akan membahas alat yang dapat dijadikan guru untuk menghasilkan pembelajaran bermakna yaitu melalui jurnal refleksi. Jurnal refleksi bukan ringkasan materi pembelajaran tetapi lebih fokus pada refleksi diri dan hasil pemikiran siswa terhadap apa yang dipelajari (Septiyana, 2013). Kajian ini dilakukan untuk membantu guru dalam menciptakan pembelajaran yang mengintegrasikan iman dan pembelajaran.

Menurut Shuell (2010) terdapat 3 fase pembelajaran bermakna, yaitu fase awal, fase tengah, dan fase terminal. Fase awal pembelajaran yaitu siswa memperoleh gambaran besar fakta dengan potonganpotongan informasi yang masih terpisah. Pada fase tengah, siswa mulai melihat kesamaan dan hubungan di antara informasi-informasi yang diperoleh. Pada fase terminal, pengetahuan sudah mulai terstruktur dan kondisi terhubungnya pengetahuan awal dan pengetahuan baru terbangun dengan lebih baik. Saat siswa sudah melewati ketiga fase ini, maka pembelajaran yang dialami dapat dikatakan mencapai pembelajaran yang bermakna.

Van Brummelen (2009) juga menjelaskan 4 fase pembelajaran yang selaras dengan fase pembelajaran Shuell (2010), yaitu fase menentukan situasi, fase penyingkapan, fase reformulasi, dan fase transenden. Pada fase pertama sampai ketiga, terdapat kesamaan proses pembelajaran. Fase keempat yang dijelaskan oleh Van Brummelen (2009), siswa tidak hanya sampai pada menghubungkan pengetahuan awal dan pengetahuan baru tetapi siswa dapat bergerak di luar batas dengan respon yang bertanggung jawab melalui kegiatan reflektif yang menjadi kesatuan pembelajaran yang bermakna.
Fiddler \& Marienau (2008) menjelaskan bahwa pengalaman yang merujuk pada pembelajaran bermakna merupakan bagian peranan dari refleksi. Hal ini disebabkan karena refleksi diikuti dengan evaluasi atas pengalaman, perasaan, dan pengetahuan awal yang menghasilkan tindakan lebih lanjut (Poldner, Schaaf, Simons, \& Tartwijk, 2014).

Penelitian mencatat bahwa penulisan jurnal mendorong pemikiran siswa melalui proses kognitif yang berbeda seperti prediksi, tukar pikiran, refleksi, dan bertanya sehingga dapat memacu siswa untuk mengungkapkan ketertarikan, pemikiran, dan keingintahuan tentang dunia di sekitar mereka dan menemukan ide baru (Al-rawahi \& Al-balushi, 2015). Berdasarkan penelitian Fauziya \& Suhara (2015) diperoleh bahwa jurnal refleksi berbasis penilaian diri mampu membuat siswa menyatakan pengetahuan baru yang dipelajari dan menghubungkannya dengan pengetahuan yang sudah ada sebelumnya sehingga mampu mengambil tindakan yang lebih lanjut.

Proses menemukan makna yang dikemas di dalam jurnal refleksi ini diharapkan dapat menuntun siswa dalam memahami makna sesungguhnya dalam mempelajari kimia. Kimia sebagai ilmu yang menyelidiki fenomena alam dapat menjadi sarana bagi guru dan siswa untuk mengekplor dunia yang mengarah kepada Allah. Setiap orang percaya dipanggil untuk menemukan tanda jari Allah di dalam alam dan mengerti akan tujuan dan kehendak Allah terhadap ciptaan-Nya (Van Oudtshoorn, 2014). Guru Kristen terpanggil untuk menemukan tanda jari Allah sambil membantu siswa melihat hal yang sama di dalam pembelajaran Kimia. Tujuannya yaitu agar siswa bisa memaknai pembelajaran kimia dengan pemahaman yang benar sehingga dapat menghasilkan respon yang benar.

\section{Metode Penelitian}

Penelitian ini dilakukan dengan menggunakan metode studi literatur. Digunakan 
berbagai jurnal dan buku sebagai sumber data utama yang mendukung pembahasan. Sumber data utama dianalisis dan dikaji sehingga mampu menjawab tujuan penelitian ini.

Sebelumnya, observasi dilakukan saat Program Pengenalan Lapangan 2 di salah satu sekolah di Jakarta. Kelas yang diobservasi adalah kelas X dengan jumlah 23 siswa. Proses mengajar dilakukan selama satu bulan dengan total pertemuan yaitu 8 kali pertemuan mengajar.

Sumber data tambahan berupa hasil refleksi guru saat mengajar serta hasil refleksi siswa saat belajar. Data tambahan digunakan untuk memperkuat masalah dan tambahan dalam pembahasan.

\section{Hasil Penelitian dan Pembahasan}

Teori pembelajaran bermakna didasari oleh teori Ausubel yang menjelaskan bahwa pembelajaran bermakna dapat terjadi jika pengetahuan yang sudah dimiliki siswa dapat berinteraksi dengan pengetahuan yang baru (West \& Fensham, 2014). Pembelajaran bermakna juga berkaitan dengan pembelajaran kontekstual karena melibatkan unsur kehidupan nyata siswa (Gazali, 2016). Artinya, ketika pengetahuan awal dan pengetahuan baru siswa saling terkoneksi karena adanya hubungan dengan kehidupan nyata siswa, maka siswa sudah mencapai pembelajaran bermakna.

Berdasarkan pengertian di atas, bagaimana menjelaskan hubungan pembelajaran bermakna dengan pembelajaran yang reflektif? Penjelasan yang pertama yaitu dari segi proses pembelajarannya. Penulis menggunakan proses pembelajaran yang dikemukakan oleh Shuell (2010). Sebelum siswa mencapai pembelajaran bermakna, siswa mengalami proses menghubungkan berbagai konsep. Konsep-konsep yang sebelumnya sudah melekat pada siswa masih berdiri secara terpisah dengan konsep-konsep yang baru dipelajari siswa. Pada tahap pertama ini, pengetahuan baru yang diperoleh siswa di

52

Copyright (C) 2020 JEC | ISSN 2715-3029 (p) 2685-4880 (e)

Volume 2, Nomor 2, 2020 dalam pembelajaran hanya berupa fakta mentah yang belum memiliki taraf keberartian bagi siswa.

Tahap kedua, siswa mulai melihat koneksi antara berbagai konsep. Hal ini bisa berupa kemiripan antara satu konsep dengan konsep yang lain, bisa juga berupa penerapan satu konsep pada konsep yang lain. Hubungan antara konsep yang mulai dibangun pada tahap ini disebabkan oleh adanya pemeriksaan atas asumsi, kepercayaan, model mental, serta nilai (Fiddler \& Marienau, 2008). Artinya, pada tahap ini siswa mulai memilah serta memeriksa setiap konsep yang dipelajari. Ketika suatu konsep yang baru mulai dirasakan memiliki hubungan dengan konsep yang sudah ada, siswa sudah berada pada tahap menuju pembelajaran bermakna.

Proses mencapai pembelajaran bermakna yang terjadi di tahap kedua ini kemudian bisa dijelaskan melalui pembelajaran reflektif. Kondisi ketika siswa mulai menghubungkan berbagai konsep membutuhkan pemikiran yang mendalam bagi siswa karena adanya pengujian dan pemeriksaan atas pengetahuan baru yang dialami siswa. Poldner, Schaaf, Simons, \& Tartwijk (2014) menjelaskan bahwa refleksi meliputi evaluasi atas pengalaman, perasaan, dan pengetahuan awal yang menghasilkan tindakan lebih lanjut. Pada saat siswa berefleksi, siswa mulai memikirkan tentang suatu pengetahuan yang diperoleh dari pengalaman dengan lebih mendalam karena adanya proses evaluasi.

Bagan dari model pembelajaran Fiddler \& Marienau (2008) merupakan proses refleksi yang kemudian merujuk kepada pembelajaran bermakna. Kejadian yang cukup menarik perhatian kemudian menjadi satu pengalaman bagi siswa. Bentuk-bentuk perhatian yang bisa menarik siswa bisa berupa suasana, hal-hal yang menonjol, atau hal-hal yang secara khusus menjadi fokus siswa. Pengalaman-pengalaman yang cukup menarik perhatian siswa kemudian masuk pada tahap refleksi. Selama proses 
refleksi, terjadi pemeriksaan kembali atas berbagai fakta, ide, teori yang diperoleh dari pengalaman baru siswa. Pada tahap ini, siswa mulai memroses berbagai pengetahuan baru dihubungkan dengan apa yang sebelumnya sudah diketahui siswa. Proses ini kemudian merujuk pada pertanyaan, "Apakah hal ini bernilai bagi saya?" "Mengapa hal ini bernilai bagi saya?".

Ketika siswa sudah mulai menemukan koneksi dari setiap konsep, siswa mulai merumuskan suatu konsep yang utuh yang dibangun dari konsep-konsep yang berbeda. Konsep yang utuh ini kemudian menjadi hal yang bisa dipercaya siswa, memiliki signifikansi dengan kehidupan siswa, hingga melahirkan tindakan selanjutnya. Pada tahap ini, siswa berhasil menemukan pembelajaran yang bermakna.

Tahap ketiga yang dikemukakan oleh Shuell (2010) merupakan tahap terakhir pada pembelajaran bermakna. Pada tahap ini, pengetahuan sudah terstruktur dan koneksi antara pengetahuan lama dan yang baru sudah ada. Jika tahap terakhir menurut Shuell (2010) hanya sampai pada koneksi pengetahuan, bagan yang diambil dari model Fiddler \& Marienau (2008) dan teori dari Van Brummelen (2009) sedikit berbeda. Van Brummelen (2009) menambahkan bahwa jika siswa mampu bergerak di luar batas dengan respon tanggung jawab maka siswa mampu menemukan pembelajaran yang bermakna. Respon siswa bisa berbeda-beda, mulai dari perubahan pola pikir, kepercayaan, sampai dengan perubahan tingkah laku.

Penjelasan di atas merupakan penjelasan yang menjembatani antara refleksi dan pembelajaran bermakna. Proses yang terjadi di dalam refleksi membantu siswa untuk menemukan makna. Berdasarkan proses ini, penemuan makna terjadi ketika siswa mampu mengkonsepkan sendiri suatu konsep utuh yang memiliki signifikansi dalam kehidupan siswa sehingga mampu melahirkan tindakan dan tanggung jawab.
Pertanyaan selanjutnya adalah, makna apa yang sebenarnya dimaksudkan guru agar siswa bisa merasakannya? Beragamnya nilainilai yang dipetik siswa baik di dalam sekolah maupun di luar sekolah membuat siswa bisa mengkonsepkan makna yang berbeda-beda.

Merujuk pada penjelasan Van Oudtshoorn (2014), bahwa setiap orang percaya dipanggil untuk menemukan tanda jari Allah di dalam alam dan mengerti akan tujuan dan kehendak Allah terhadap ciptaan-Nya. Artinya, dalam proses menemukan makna siswa perlu menyadari bahwa dia dipangil untuk menemukan tanda jari Allah dalam pelajaran Kimia sekalipun. Hal ini menjadi penting karena ketika siswa bisa melihat Allah dalam pembelajaran Kimia, perlahan-lahan siswa bisa mengerti tujuan dari setiap proses belajarnya sehingga mampu belajar dengan perspektif yang benar.

Pemahaman ini kemudian mengantar penulis untuk membahas bagaimana mengemas refleksi yang dapat menuntun siswa agar siswa dapat menemukan makna dalam perspektif yang benar. Penulis menggunakan jurnal refleksi sebagai alat untuk membantu siswa menemukan makna setelah melihat beberapa keunggulan dari jurnal refleksi, antara lain penelitian oleh Al-rawahi \& Al-balushi (2015), penelitian Fauziya \& Suhara (2015), dan penelitian oleh Dunlap (2006).

Berdasarkan keunggulan ini, jurnal refleksi dapat membantu siswa untuk memroses berbagai informasi melalui pertanyaan panduan sehingga dapat mengarahkan siswa untuk membentuk satu konsep signifikan. Jurnal refleksi ini dikemas dengan konteks pembelajaran Kimia, di dalam koridor persepektif Kristen. Penulis merumuskan bahwa jurnal refleksi dapat dikemas dengan mempertimbangkan komponen di bawah ini:

1. Mencakup proses menghubungkan pengetahuan lama dan pengetahuan baru (West \& Fensham, 2014).

2. Memuat konteks dan esensi pembelajaran kimia (Kirna, 2012). 
3. Merujuk kepada pemikiran tentang Allah (Van Oudtshoorn, 2014).

Komponen-komponen di atas dapat menjadi pertimbangan guru dalam menyusun pertanyaan-pertanyaan yang dapat mengugah kemampuan berpikir siswa. Pertanyaan yang digunakan dapat berupa hal-hal apa saja yang menarik bagi siswa dan mengapa hal tersebut menarik dan penting bagi siswa. Hal-hal yang menarik bisa berupa fakta-fakta kimia yang dipelajari di dalam kelas yang kemudian dianggap memiliki signifikansi dengan kehidupan siswa. Pertanyaan bisa berupa halhal apa yang diketahui siswa sebelum dan sesudah mempelajari materi tertentu. Kemudian, pertanyaan merujuk pada bagaimana siswa melihat Allah di balik setiap fakta Kimia yang mereka pelajari. Di bagian akhir refleksi dapat memuat pertanyaan tentang apa yang akan dilakukan siswa terkait dengan pembelajaran yang baru saja mereka pelajari.

Sebelum menggunakan jurnal refleksi guru juga perlu memperhatikan beberapa pertanyaan-pertanyaan yang berkaitan dengan lingkungan belajar siswa. Apakah siswa berada pada level pengenalan jurnal refleksi atau sudah terbiasa mengerjakan jurnal refleksi, fase jurnal seperti apa yang cocok dengan kondisi siswa, dan hal apa yang ingin direfleksikan oleh siswa (Coulson \& Harvey, 2013). Kondisi siswa dalam mengerjakan refleksi akan berpengaruh pada kualitas refleksi yang akan dihasilkan. Jika guru menggunakan refleksi dengan pertanyaan yang terlalu mendalam pada siswa yang baru belajar menggunakan jurnal, maka hasil yang akan diperoleh tidak akan maksimal. Penting bagi guru untuk menyiapkan siswa sebelum mengerjakan jurnal agar refleksi yang dihasilkan keluar dari pemikiran reflektif siswa yang mendalam.

Jurnal refleksi (Spalding \& Vegas (2002) menjelaskan bahwa berpikir adalah keadaan alamiah tetapi kebiasaan untuk berefleksi perlu diajarkan karena di dalamnya mengandung pemikiran yang terbuka, kesungguhan hati, dan tanggung jawab. Pembuatan jurnal sebaiknya tidak hanya dilakukan selama satu kali, tetapi berkali-kali dalam periode waktu tertentu untuk membawa siswa belajar berpikir lebih dalam dan terlatih untuk menemukan makna dari setiap pembelajarannya. Terdapat serangkaian proses yang harus dialami siswa dalam proses menemukan makna. Hal inilah yang menyebabkan pembuatan refleksi harus dengan pemikiran terbuka, bersungguh-sungguh, dan bertanggung-jawab.

Guru juga perlu mengakui bahwa ketika siswa belajar di kelas, terdapat berbagai hambatan belajar khususnya dalam mempelajari kimia. Hal ini disebabkan oleh konsep-konsep kimia yang terkenal abstrak sehingga sulit untuk dipelajari (Indira, 2014; Kirna, 2012; Rosa, 2012). Kesulitan belajar yang dipengarui oleh karakteristik materi terkadang membuat siswa belum mengerti pembelajaran di dalam kelas. Guru tidak bisa menutup kemungkinan bahwa siswa tidak 'memperoleh apa-apa' selama pembelajaran kimia. Di sisi lain, guru juga bisa melihat kesulitan siswa ketika siswa memberikan respon tidak mengerti di dalam refleksi yang dituliskan.

Setelah memperhatikan beberapa hal di atas, penulis menyusun alur pembuatan dan penerapan jurnal refleksi untuk membantu siswa menemukan makna:

1. Mengamati kondisi siswa

Guru perlu melihat situasi dan kondisi siswa sebelum menerapkan jurnal refleksi. Kondisi yang dimaksud bisa berupa pengetahuan awal siswa tentang jurnal refleksi (apakah siswa sudah mengetahui jurnal refleksi) atau intensitas (seberapa sering) siswa mengakses jurnal refleksi.

2. Menyusun jurnal refleksi

Guru dapat menyusun jurnal yang memuat tiga komponen (proses menghubungkan pengetahuan awal dan baru, konteks kimia, di bawah koridor persepktif Kristen). Pertanyaan disusun berdasarkan kondisi yang diamati guru sebelumnya. Jika siswa belum pernah mengakses jurnal refeksi, guru dapat mengawali dengan pertanyaan- 
pertanyaan sederhana pada pertemuanpertemuan awal.

3. Menyiapkan siswa

Sebelum jurnal diterapkan, guru perlu menyiapkan siswa dengan memberi pemahaman tentang jurnal refleksi. Guru perlu memastikan bahwa siswa mengerti tentang jurnal refleksi dan bagaimana menjawab pertanyaan-pertanyaan penuntun. Guru juga perlu memberitahu hal-hal yang diharapkan melalui jurnal refleksi agar siswa mengerti dan memiliki gambaran ketika menulis jurnal refleksi. Pengondisian juga bisa dilakukan oleh guru, misalnya kapan jurnal dikumpul, intensitas pengerjaan jurnal, atau penilaian yang dilakukan guru melalui jurnal refleksi.

4. Menerapkan jurnal refleksi

Setelah ketiga langkah dilakukan, guru dapat menerapkan jurnal refleksi kepada siswa. Penting bagi guru untuk mengalokasikan waktu bagi siswa untuk mengerjakan jurnal refleksi agar siswa memiliki waktu khusus untuk mencerna pembelajaran.

Setelah keempat langkah dilakukan, guru dapat terus mengulang alur ini sesuai dengan pembelajaran. Proses pengerjaan refleksi perlu dilakukan berulang kali agar siswa semakin terlatih berefleksi dan menemukan makna di setiap pembelajaran. Guru perlu mengingat bahwa pengerjaan jurnal untuk menemukan makna adalah proses berkelanjutan, sehingga setiap pengerjaannya adalah proses bagi siswa untuk menemukan makna.

Kemungkinan beragam yang bisa terjadi setelah jurnal refleksi diterapkan dapat menjadi evaluasi bagi guru. Secara tidak langsung, refleksi merupakan cerminan dari pembelajaran yang terjadi di dalam kelas. Penting bagi guru membawa pembelajaran kimia menarik dengan menyuguhkan fakta-fakta yang berkenaan dengan kehidupan siswa. Sulit bagi siswa untuk memaknai pembelajaran kimia yang bisa membawa pertumbuhan iman ketika guru juga tidak memaknai dan tidak menghidupi makna yang diperoleh dari pembelajaran kimia. Guru bisa membagikan makna yang secara pribadi dialami guru saat mempelajari kimia dan bagaimana makna tersebut berdampak pada kehidupan iman guru. Jurnal refleksi ini penting untuk diterapkan karena dapat menjadi sarana bagi guru untuk menciptakan ruang berpikir yang melampaui materi pembelajaran dengan pemahaman dan respon yang benar.

Pembuatan jurnal dengan konteks pembelajaran kimia di bawah perspektif tentang Allah membawa guru untuk menggali lebih dalam apa makna yang diperoleh guru saat mempelajari kimia. Kimia mempelajari partikel kecil yang tidak bisa dilihat mata namun menjelaskan fenomena yang terlihat oleh mata. Keberadaan partikel kecil yang disebut atom ini memang terlalu kecil sehingga sulit untuk dinyatakan dalam bentuk fisik. Itulah mengapa banyak siswa mengklaim bahwa mempelajari kimia itu sulit. Guru perlu membawa siswa untuk melihat keindahan yang ditunjukkan di dalam kimia sehingga pada akhirnya siswa heran dan takjub tentang fakta-fakta yang mereka pelajari.

Tujuan akhir dari jurnal refleksi dengan konteks pembelajaran kimia di bawah perspektif tentang Allah diharapkan dapat membawa siswa berpikir lebih dalam tentang dirinya dan hubungannya dengan iman kepada Allah. Setiap proses yang dialami siswa yang terdiri dari pengertian dan kesulitan diharapkan dapat membuat siswa kembali kepada Allah. Guru perlu mengingat bahwa pembelajaran bermakna tidak hanya dialami oleh siswa tetapi juga dialami oleh guru. Ketika guru dan siswa mampu untuk mengerti berbagai konsep kimia, siswa dan guru bersyukur atas anugerah yang Allah singkapkan. Ketika guru dan siswa mengalami kesulitan dalam mempelajari kimia, keduanya menyadari bahwa guru dan siswa adalah ciptaan yang terbatas namun bersamasama berproses dalam menggunakan akal yang Allah karuniakan. 


\section{Simpulan}

Bagian Jurnal releksi dapat dijadikan alat untuk menuntun siswa dalam menemukan makna pada pelajaran kimia karena proses pengerjaan jurnal refleksi melibatkan proses berpikir, pengujian atas asumsi dan kepercayaan, serta penemuan hal signifikan sehingga siswa mampu menghubungkan pengetahuan awal dan pengetahuan baru yang menghasilkan respon bertanggung jawab.

\section{Daftar Pustaka}

Al-rawahi, N. M., \& Al-balushi, S. M. (2015). The Effect of Reflective Science Journal Writing on Students' Self-Regulated Learning Strategies. International Journal of Environmental \& Science Education, 10(3), 367-379.

Argandi, R., \& Martini, K. S. (2013). Pembelajaran Kimia dengan Metode Inquiry Terbimbing dilengkapi Kegiatan Laboratorium Real dan Virtual pada Pokok Bahasan Pemisahan Campuran. Jurnal Pendidikan Kimia, 2(2), 44-49.

Coulson, D., \& Harvey, M. (2013). Scaffolding Student Reflection for Experience-Based Learning: a Framework. Teaching in Higher Education, 18(4), 401-414.

Fauziya, D. S., \& Suhara, A. M. (2015). Evaluasi Pembelajaran melalui Penulisan Jurnal Reflektif Berbasis Penilaian Diri di PBS Indonesia STKIP Siliwangi. Jurnal Ilmiah UPT P2M STKIP SIliwangi, 2(1), 46-52.

Fiddler, M., \& Marienau, C. (2008). Developing Habits of Reflection for Meaningful Learning. New Directions for Adult and Continuing Education, (118), 75-86.

Gazali, R. Y. (2016). Pembelajaran Matematika yang Bermakna. Jurnal Pendidikan Matematika, 2(3), 181-190.

56

Copyright (C) 2020 JEC | ISSN 2715-3029 (p) 2685-4880 (e)

Volume 2, Nomor 2, 2020
Indira, C. (2014). Best-Practices Pendekatan Saintifik dada Pembelajaran Kimia di SMA Negeri 4 Sampit. Kaunia, 10 (2), 141-151.

Kirna, I. M. (2012). Pembelajaran Berbantuan Multimedia Interaktif. Jurnal IImu Pendidikan, 18(1), 88-97.

Poldner, E., Schaaf, M. Van Der, Simons, P. R., \& Tartwijk, J. Van. (2014). Assessing Student Teachers' Reflective Writing Through Quantitative Content Analysis. European Journal of Teacher Education, 37(3), 348373.

Rosa, N. M. (2012). Pengaruh Sikap pada Mata Pelajaran Kimia dan Konsep Diri terhadap Prestasi Belajar Kimia. Jurnal Formatif, 2(3), 218-226.

Septiyana, K. (2013). Penerapan Jurnal Belajar sebagai Strategi Berpikir Metakognitif pada Materi Sistem Imunitas terhadap Hasil Belajar Peserta didik SMA Negeri 1 Kajen. Unnes Journal of Biology Education, 2(1), 1-9.

Shuell, T. J. (2010). Phases of meaningful learning. Review of Educational Research, 60(4), 531-547.

Spalding, E., \& Vegas, L. (2002). Demystifying Reflection: A Study of Pedagogical Strategies That Encourage Reflective Journal Writing. Teachers College Record, 104(7), 1393-1421.

Van Brummelen, H. (2009). Berjalan dengan Tuhan di dalam Kelas: Pendekatan Kristiani untuk Pembelajaran. Jakarta: Universitas Pelita Harapan Press.

Van Oudtshoorn, A. (2014). Taking a New Look at General Revelation. Australian EJournal of Theology, 21(3), 248-261.

West, L. H. T., \& Fensham, P. J. (2014). Prior Knowledge and the Learning of Science. Studies in Science Education, 1(1), 61-81. 